Supporting Information

\title{
Piezobiocatalysis: Ultrasound-Driven Enzymatic Oxyfunctionalization of C-H Bonds
}

Jaeho Yoon ${ }^{\mathrm{a}}$, Jinhyun Kim ${ }^{\mathrm{a}}$, Florian Tieves ${ }^{\mathrm{b}}$, Wuyuan Zhang ${ }^{\mathrm{b}}$, Miguel Alcalde ${ }^{\mathrm{c}}$, Frank Hollmann* , and Chan Beum Park*a

${ }^{a}$ Department of Materials Science and Engineering, Korea Advanced Institute of Science and Technology (KAIST), 335 Science Road, Daejeon 305-701, Republic of Korea.

${ }^{\mathrm{b}}$ Department of Biotechnology, Delft University of Technology, Van der Maasweg 9, Delft 2629HZ, The Netherlands.

${ }^{\mathrm{c}}$ Department of Biocatalysis, Institute of Catalysis, CSIC, 28049 Madrid, Spain.

*Email: parkcb@kaist.ac.kr (C.B.P), f.hollmann@tudelft.nl (F.H.) 


\section{Experimental Procedures}

Chemicals: All the chemicals, such as bismuth(III) nitrate pentahydrate, potassium chloride, tris(hydroxymethyl)aminomethane (Tris), peroxidase from horseradish (HRP), and 2,2'azino-bis(3-ethylbenzothiazoline-6-sulphonic acid) (ABTS), nitro blue tetrazolium (NBT), and terephthalic acid (TA), were purchased from Sigma-Aldrich (St. Louis, MO, USA).

Piezocatalyst preparation: $\mathrm{BiOCl}$ microsheets were synthesized via one-pot hydrothermal treatment. We dissolved $2 \mathrm{mmol}$ of $\mathrm{Bi}\left(\mathrm{NO}_{3}\right)_{3}$ and $2 \mathrm{mmol}$ of $\mathrm{KCl}$ in $30 \mathrm{~mL}$ deionized water (18.2 $\mathrm{M} \Omega \mathrm{cm}$ at $25{ }^{\circ} \mathrm{C}$ ) at room temperature, and stirred the mixture for $1 \mathrm{~h}$. Then, the solution was sealed in a $50 \mathrm{~mL}$ poly(tetrafluoroethylene) (Teflon)-lined stainless steel autoclave, and heated at $180{ }^{\circ} \mathrm{C}$ for $24 \mathrm{~h}$. After we cooled the autoclave down to room temperature, the solution was filtered through a Whatman ${ }^{\circledR}$ nylon membrane (pore size: 0.2 $\mu \mathrm{m})$ to collect $\mathrm{BiOCl}$ microsheets. The microsheets were washed with ethanol and deionized water for several times and dried at $60^{\circ} \mathrm{C}$ for $8 \mathrm{~h}$. The purified $\mathrm{BiOCl}$ was placed in an empty vial and stored at $4{ }^{\circ} \mathrm{C}$ for further experiments.

Enzyme preparation: The evolved peroxygenase mutant from Agrocybe aegerita (rAaeUPO) was obtained via recombinant expression in Pichia pastoris according to the literature. ${ }^{1}$ The specific activity of $\mathrm{r} A a e \mathrm{UPO}$ was estimated to be $66.2 \pm 4.2 \mathrm{U} \mathrm{mg}^{-1}$. One unit of enzyme activity was defined as the amount of enzyme catalyzing the oxidation of $1 \mu \mathrm{mol}$ of ABTS per minute in a sodium citrate buffer (100 mM, pH 4.4). 
Material Characterization: The crystallinity of $\mathrm{BiOCl}$ was examined using a SmartLab X-ray diffractometer (Rigaku Co., Japan) with a $\mathrm{Cu} \mathrm{K \alpha 1}$ radiation (wavelength: $1.5406 \AA$ ). The morphology of $\mathrm{BiOCl}$ was investigated using an S-4800 scanning electron microscope (Hitachi, Japan) at $10 \mathrm{kV}$ and a Tecnai G2 F30 S-Twin Field emission TEM (FEI., USA) at $300 \mathrm{kV}$. The element analyses were performed using an X-ray photoelectron spectroscopy (Thermo VG Scientific Inc., UK).

Piezocatalytic $\mathrm{H}_{2} \mathrm{O}_{2}$ production: We dissolved $\mathrm{BiOCl}$ in a $5 \mathrm{ml}$ of a Tris-buffered solution (50 $\mathrm{mM}, \mathrm{pH} 7.0, \mathrm{O}_{2}$ or $\mathrm{N}_{2}$ purged), and sonicated the solution using an ultrasonic cleaner (Branson CPX1800H-E, Branson, USA). Note that $\mathrm{O}_{2}$ or $\mathrm{N}_{2}$ gas were continuously purged into the solution through a Teflon tube (diameter: $1 \mathrm{~mm}$ ) during the piezocatalysis. The concentration of $\mathrm{H}_{2} \mathrm{O}_{2}$ was quantified using HRP-catalyzed oxidation of ABTS. We added 50 $\mu \mathrm{l}$ of reaction sample to $950 \mu \mathrm{l}$ of the reagent solution, and incubated for $10 \mathrm{~min}$ at room temperature; the reagent solution was prepared by dissolving $2 \mathrm{mM}$ ABTS and $2.5 \mathrm{U}$ HRP in a potassium phosphate buffer $(100 \mathrm{mM}, \mathrm{pH} 5.0)$. The incubated sample was centrifuged for 1 min at 10,000 rpm to remove BiOCl. Then, we used a V-650 spectrophotometer (JASCO Inc., Japan) to monitor an absorbance of the supernatant at $420 \mathrm{~nm}$.

Piezocatalysis: BiOCl, rAaeUPO, and a substrate were dissolved in a $5 \mathrm{ml}$ Tris-buffered solution (50 mM, pH 7.0, $\mathrm{O}_{2}$ or $\mathrm{N}_{2}$ purged). Note that the reaction solution was sonicated and continuously purged with $\mathrm{O}_{2}$ or $\mathrm{N}_{2}$ gas during piezobiocatalysis. To quantify the enzymatic product, we collected $50 \mu \mathrm{l}$ of a reaction sample, and extracted organic products using ethyl acetate (containing $5 \mathrm{mM}$ 1-octanol as internal standard). The organic phase was carefully collected and dried with $\mathrm{MgSO}_{4}$, followed by centrifugation at 15,000 rpm for $1 \mathrm{~min}$. The 
organic supernatant was analyzed using a 7890A gas chromatography (Agilent Technologies Inc., USA) equipped with a CP-Chirasil-Dex CB column $(25 \mathrm{~m}, 0.32 \mathrm{~mm}, 0.25 \mu \mathrm{m})$. The oven temperature programs were tabulated in Table S1. The TTN was calculated according to the Equation S1.

$$
\mathrm{TTN}_{\text {rAaeUPO }}=\frac{\text { Maximum concentration of product }}{\text { Concentration of } \mathrm{rAaeUPO}}
$$

ROS detection: The amount of superoxide radicals $\left(\mathrm{O}_{2}{ }^{-}\right)$was estimated using the NBT reduction assay ${ }^{2}$. We added $\mathrm{BiOCl}$ and $20 \mu \mathrm{M}$ NBT in an $\mathrm{O}_{2}$-purged Tris buffer $(50 \mathrm{mM}, \mathrm{pH}$ 7.0), and applied ultrasound to the solution. After ultrasound irradiation, a change in the sample's absorbance at $259 \mathrm{~nm}$ was monitored using a V-650 spectrophotometer (JASCO Inc., Japan). The quantitative analysis of hydroxyl radicals $\left(\mathrm{OH}^{*}\right)$ was performed using the TA assay $^{2}$. We sonicated a Tris-buffered solution (50 mM, pH 7.0, $\mathrm{O}_{2}$-purged) containing BiOCl and $300 \mu \mathrm{M}$ TA. Then, the fluorescence intensity of the sample solution was recorded at 430 $\mathrm{nm}\left(\lambda_{\mathrm{ex}}=315 \mathrm{~nm}\right)$ using a FP6500 spectrofluorometer (JASCO Inc., Japan). Generation rates of $\mathrm{O}_{2}{ }^{-}$and $\mathrm{OH}^{*}$ were quantified using a calibrated NBT absorption intensity and HTA fluorescence intensity, respectively.

Enzyme activity assay: The enzymatic activity of rAaeUPO was evaluated using the peroxygenase activity assay with ABTS molecules as substrate. A reaction sample was mixed with a reagent solution $(\mathrm{v} / \mathrm{v}, 50: 950)$; the reagent solution was prepared by dissolving 0.5 $\mathrm{mM} \mathrm{H} \mathrm{H}_{2}$, and $0.5 \mathrm{mM} \mathrm{ABTS}$ in a sodium citrate buffer $(50 \mathrm{mM}, \mathrm{pH} 4.4)$. The oxidation of ABTS was monitored by change in the absorption intensity at $420 \mathrm{~nm}$ using a V-650 spectrophotometer (JASCO Inc., Japan) and activities were calculated using $\varepsilon_{420}=36.0 \mathrm{mM}^{-1}$ 
$\mathrm{cm}^{-1}$. The percent residual activity of $\mathrm{r} A a e \mathrm{UPO}$ was calculated relative to initial activity according to the Equation S2.

$$
\text { Residual activity }(\%)=\frac{\text { enzyme activity }}{\text { initial enzyme activity }} \times 100
$$




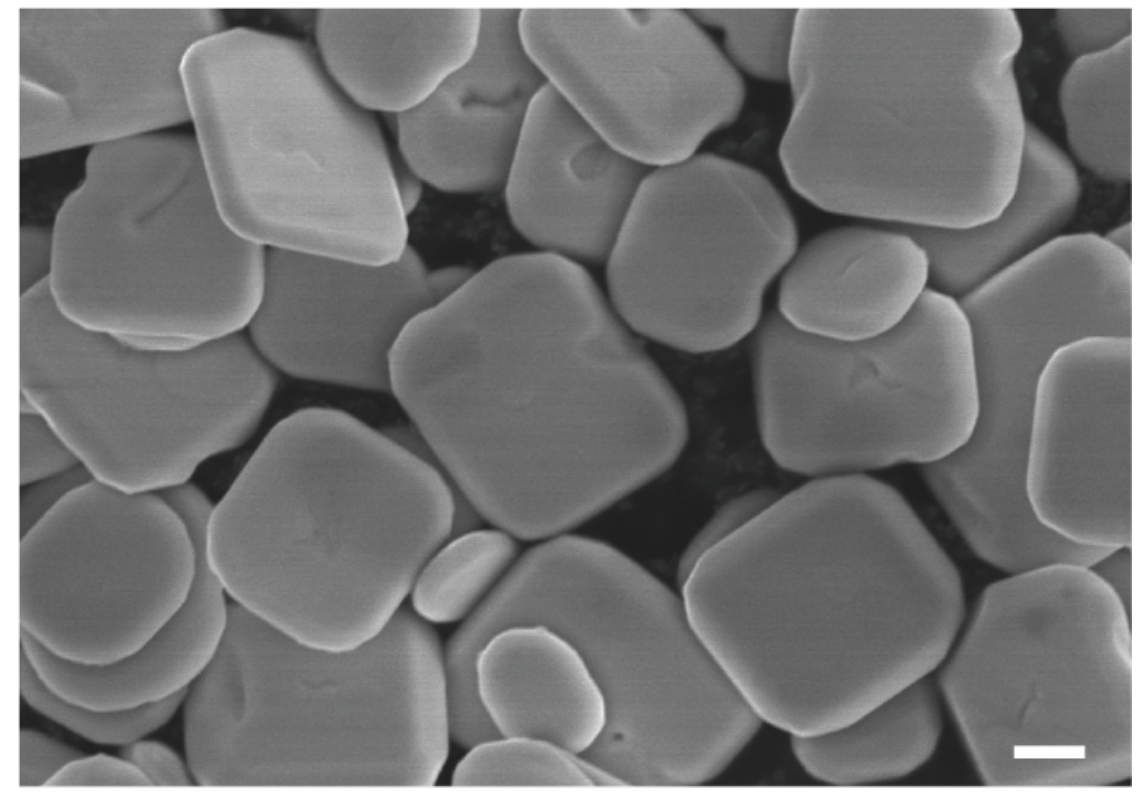

Figure S1. Sheet-shaped morphology of as-synthesized BiOCl. Scanning electron microscopic image of $\mathrm{BiOCl}$ microsheets. Scale bar: $1 \mu \mathrm{m}$.

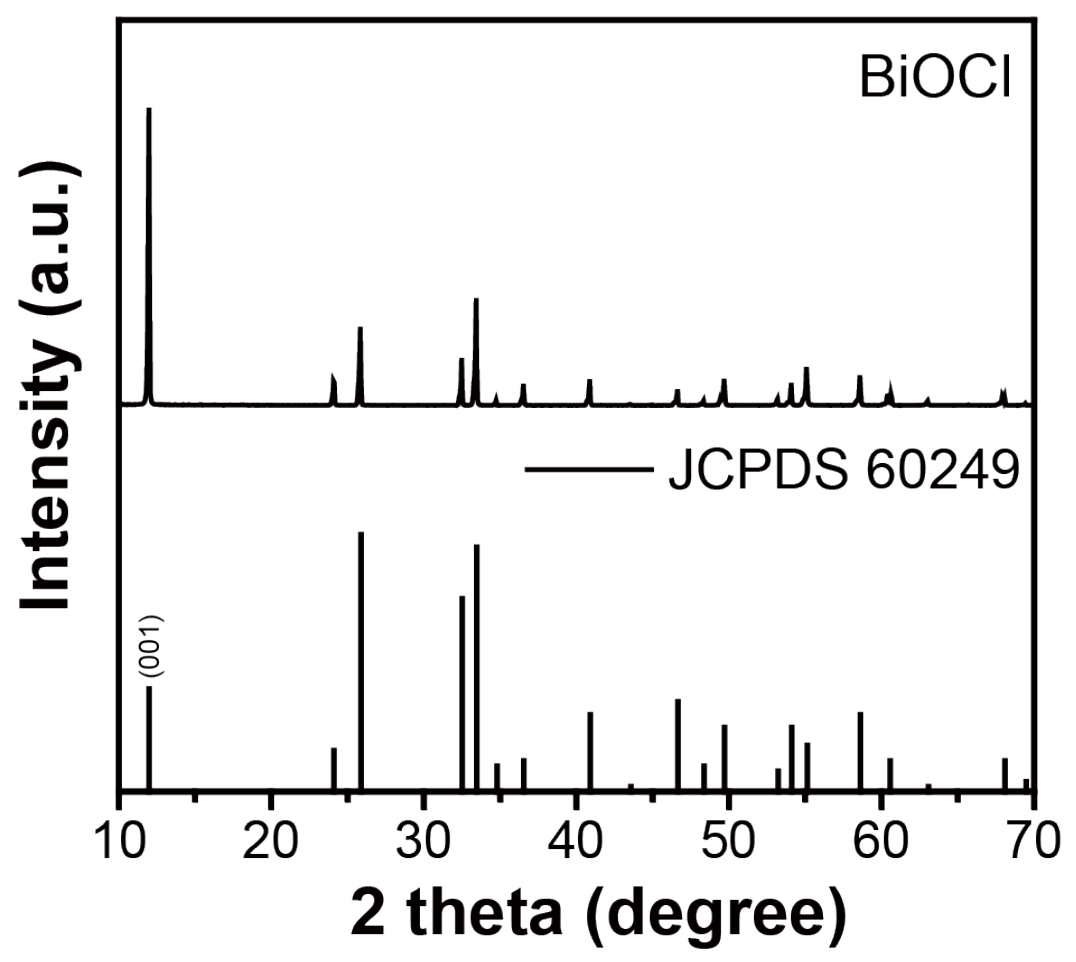

Figure S2. Crystallinity of $\mathrm{BiOCl}$. X-ray diffraction pattern of $\mathrm{BiOCl}$ microsheets. All the diffraction peaks were well-matched with the tetragonal phase of BiOCl (JCPDS No. 060249). Scan rate: $4^{\circ} \mathrm{min}^{-1}$. 


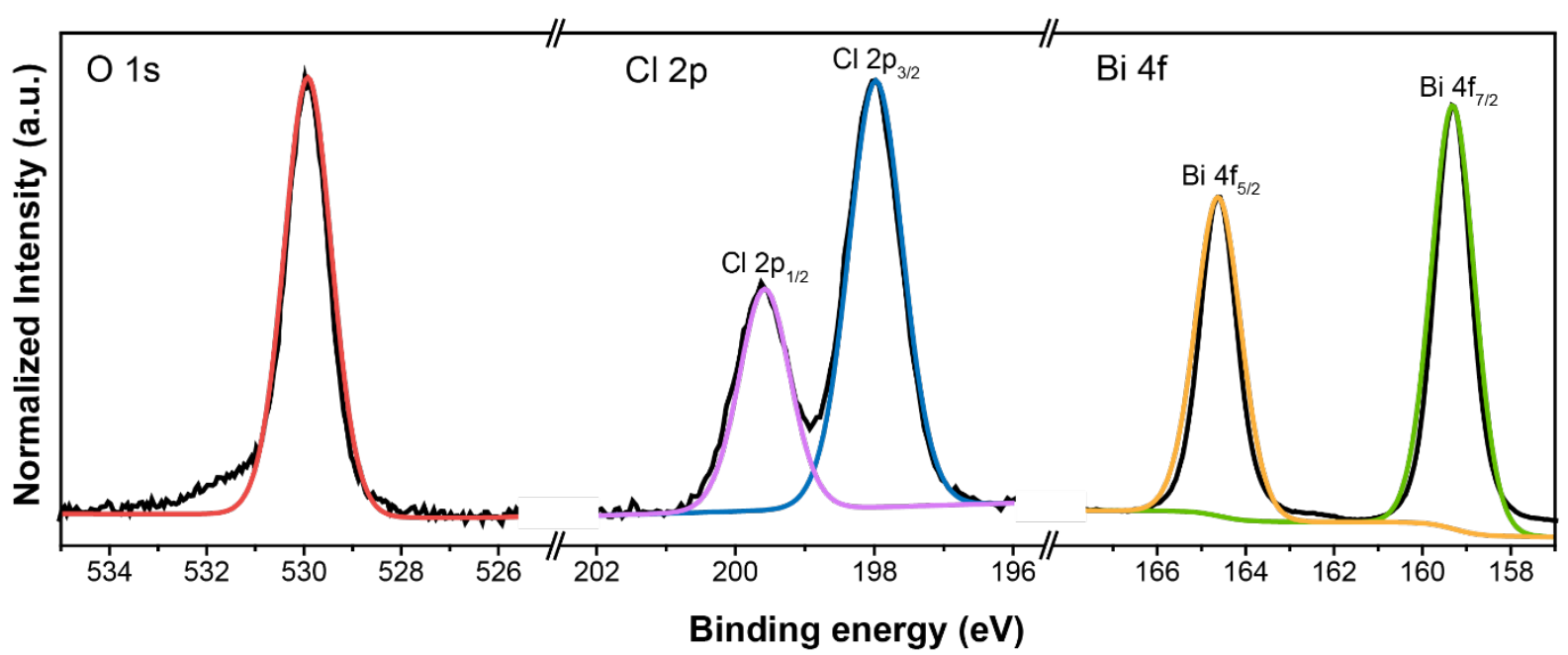

Figure S3. Chemical states and surface composition of BiOCl. X-ray photoelectron spectroscopic spectra of $\mathrm{BiOCl}$ piezocatalysts. The binding energies of $\mathrm{Bi}\left(4 \mathrm{f}_{5 / 2}\right.$ at $164.6 \mathrm{eV}$ and $4 \mathrm{f}_{7 / 2}$ at $\left.159.3 \mathrm{eV}\right), \mathrm{O}(1 \mathrm{~s}$ at $530.0 \mathrm{eV})$, and $\mathrm{Cl}\left(2 \mathrm{p}_{1 / 2}\right.$ at $199.6 \mathrm{eV}$ and $2 \mathrm{p}_{3 / 2}$ at $\left.198.0 \mathrm{eV}\right)$ corresponded to the typical XPS peaks of $\mathrm{BiOCl}$.

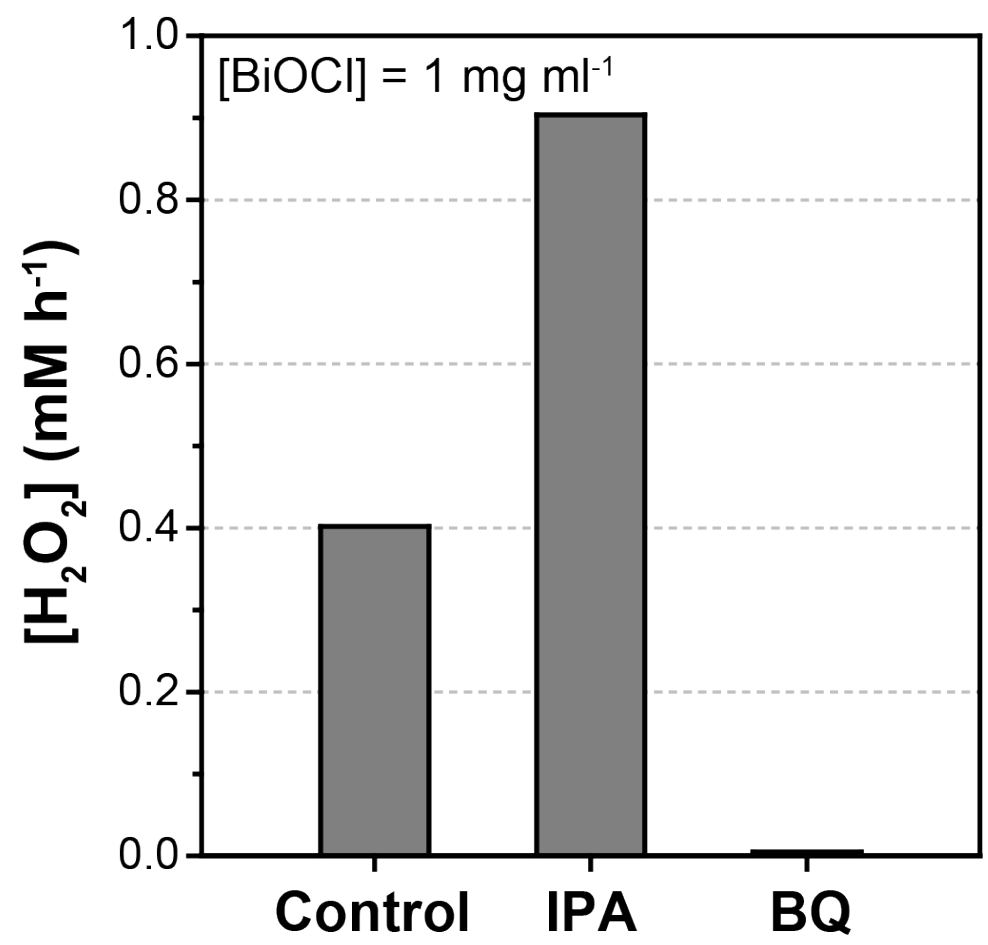

Figure S4. Influence of radical scavengers on piezocatalytic formation of $\mathrm{H}_{2} \mathrm{O}_{2}$. Isopropanol (IPA) and benzoquinone (BQ) was used as $\mathrm{OH}^{*}$ scavenger and $\mathrm{O}_{2}{ }^{-}$scavenger, respectively. Reaction conditions: $1 \mathrm{mg} \mathrm{ml}^{-1} \mathrm{BiOCl}$ and scavenger in an $\mathrm{O}_{2}$-purged Tris buffer $(50 \mathrm{mM}, \mathrm{pH}$ 7.0) under ultrasonic irradiation $(40 \mathrm{kHz}, 70 \mathrm{~W})$ for $1 \mathrm{~h}$. We did not add any radical scavengers in the control experiment. 


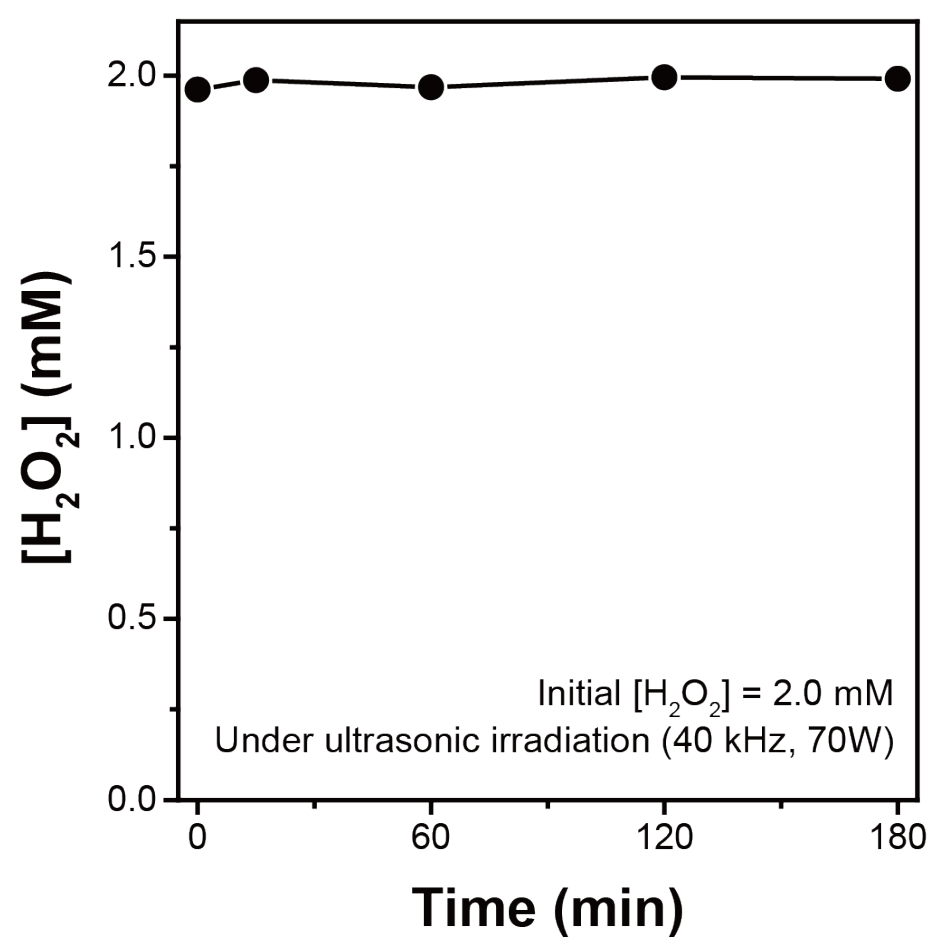

Figure S5. Effect of ultrasound wave on the $\mathrm{H}_{2} \mathrm{O}_{2} .2 \mathrm{mM} \mathrm{H}_{2} \mathrm{O}_{2}$ in a Tris buffer $(50 \mathrm{mM}, \mathrm{pH}$ 7.0) was irradiated by ultrasound wave $(40 \mathrm{kHz}, 70 \mathrm{~W})$ for $3 \mathrm{~h}$.

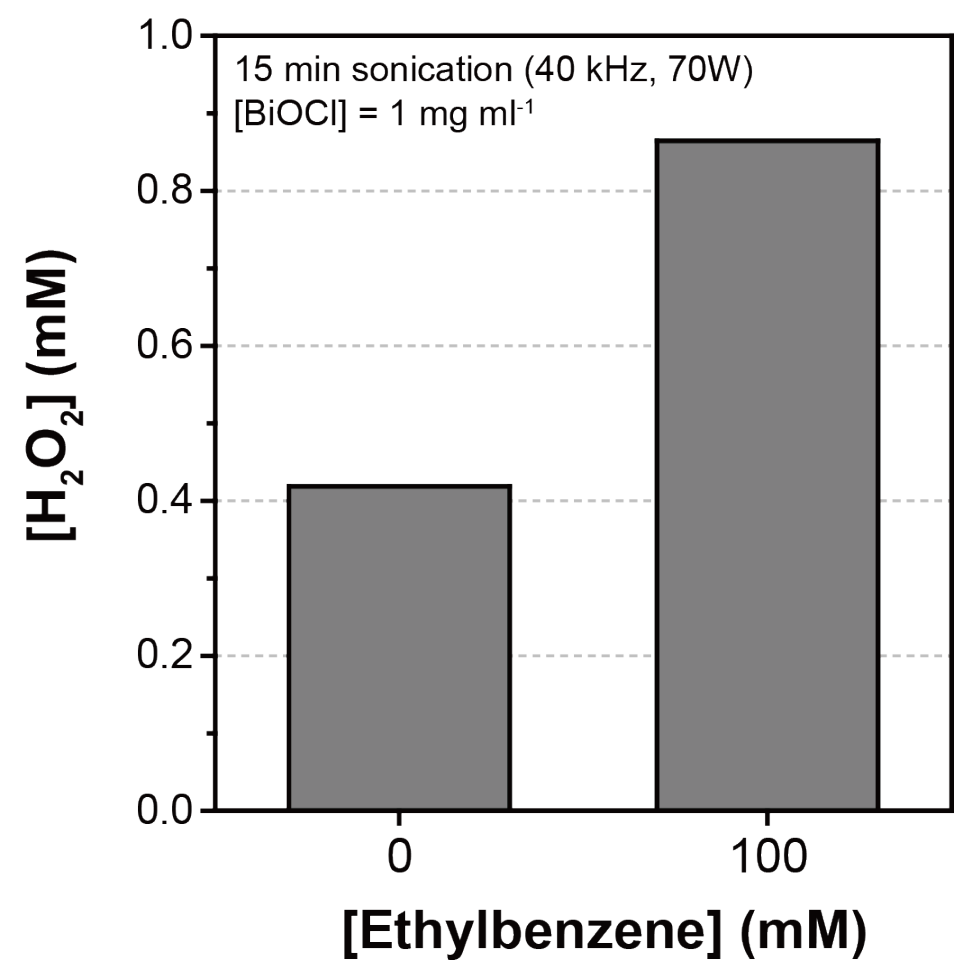

Figure S6. Influence of ethylbenzene on piezocatalytic formation of $\mathrm{H}_{2} \mathrm{O}_{2}$. Reaction conditions: $1 \mathrm{mg} \mathrm{ml}^{-1} \mathrm{BiOCl}$; applied ultrasound $(40 \mathrm{kHz}, 70 \mathrm{~W})$; solvent: an $\mathrm{O}_{2}$-purged Tris buffer (50 mM, pH 7.0). 
Table S1. GC oven temperature programs and retention times for substrates and products

\begin{tabular}{|c|c|c|}
\hline Substrate & Temperature profile & Retention time (min) \\
\hline Ethylber & $\begin{array}{l}90^{\circ} \mathrm{C} \text { for } 5 \mathrm{~min}, 20^{\circ} \mathrm{C} / \mathrm{min} \\
\text { to } 110^{\circ} \mathrm{C} \text { and hold for } 13.5 \\
\text { min, } 40{ }^{\circ} \mathrm{C} / \mathrm{min} \text { to } 180{ }^{\circ} \mathrm{C} \\
\text { and hold for } 1.5 \mathrm{~min}\end{array}$ & $\begin{array}{l}\text { Ethylbenzene: } 4.5 \\
\text { Acetophenone: } 10.5 \\
(R)-1 \text {-phenylethanol: } 18.3 \\
\text { (S)-1-phenylethanol: } 19.6 \\
\text { 1-Octanol (internal standard): } 12.7\end{array}$ \\
\hline Propylbe & $\begin{array}{l}90{ }^{\circ} \mathrm{C} \text { for } 5 \mathrm{~min}, 20^{\circ} \mathrm{C} / \mathrm{min} \\
\text { to } 130{ }^{\circ} \mathrm{C} \text { and hold for } 10 \\
\min \end{array}$ & $\begin{array}{l}\text { Propylbenzene: } 6.0 \\
(R)-1-P h e n y l-1-\text { propanol: } 14.2 \\
(S)-1-P h e n y l-1-\text { propanol: } 14.5 \\
\text { Propiophenone: } 10.3 \\
\text { 1-Octanol (internal standard): } 9.3\end{array}$ \\
\hline $\begin{array}{l}\text { 1-Chloro-4- } \\
\text { ethylbenzene }\end{array}$ & $\begin{array}{l}90{ }^{\circ} \mathrm{C} \text { for } 5 \mathrm{~min}, 20^{\circ} \mathrm{C} / \mathrm{min} \\
\text { to } 150{ }^{\circ} \mathrm{C} \text { and hold for } 7 \\
\min \end{array}$ & $\begin{array}{l}\text { 1-Chloro-4-ethylbenzene: } 7.7 \\
\text { (R)-4-Chloro- } \alpha \text {-methylbenzyl alcohol: } 14.0 \\
(S)-4-\text { Chloro- } \alpha \text {-methylbenzyl alcohol: } 14.5 \\
\text { 4'-Chloroacetophenone: } 10.8 \\
\text { 1-Octanol (internal standard): } 8.8\end{array}$ \\
\hline Cyclohexane & $\begin{array}{l}90{ }^{\circ} \mathrm{C} \text { for } 5 \mathrm{~min}, 20^{\circ} \mathrm{C} / \mathrm{min} \\
\text { to } 110^{\circ} \mathrm{C} \text { and hold for } 5 \\
\text { min, } 40^{\circ} \mathrm{C} / \mathrm{min} \text { to } 150{ }^{\circ} \mathrm{C} \\
\text { and hold for } 3 \mathrm{~min}\end{array}$ & $\begin{array}{l}\text { Cyclohexane : } 3.1 \\
\text { Cyclohexanone }: 6.8 \\
\text { Cyclohexanol }: 9.0 \\
\text { 1-Octanol (internal standard): } 12.0\end{array}$ \\
\hline cis- $\beta$-methylstyrene & $\begin{array}{l}90{ }^{\circ} \mathrm{C} \text { for } 2 \mathrm{~min}, 10^{\circ} \mathrm{C} / \mathrm{min} \\
\text { to } 140{ }^{\circ} \mathrm{C} \text { and hold for } 5 \\
\text { min, } 20^{\circ} \mathrm{C} / \mathrm{min} \text { to } 180^{\circ} \mathrm{C} \\
\text { and hold for } 3 \mathrm{~min}\end{array}$ & $\begin{array}{l}\text { cis- } \beta \text {-Methylstyrene: } 5.47 \\
(1 R, 2 S) \text {-cis- } \beta \text {-Methylstyrene oxide }{ }^{[\mathrm{a}]}: 7.7 \\
(1 S, 2 S) \text {-cis- } \beta \text {-Methylstyrene oxide: } 7.4\end{array}$ \\
\hline
\end{tabular}

[a] The concentration of $(1 R, 2 S)$-cis- $\beta$-methylstyrene oxide) was calculated using $(1 S, 2 S)$-cis- $\beta$ methylstyrene oxide as an internal standard. 
Table S2. Effect of $\mathrm{r} A \mathrm{AeUPO}$ and BiOCl concentrations on the piezobiocatalytic reaction.

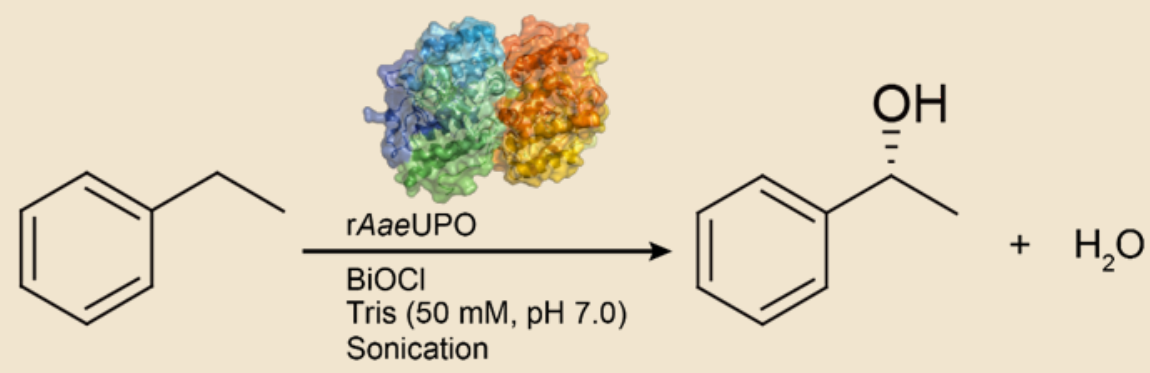

\begin{tabular}{|c|c|c|c|c|c|}
\hline Component & Concentration & $\begin{array}{l}\text { Initial } \\
\text { reaction rate }^{[\mathrm{a}]} \\
\left(\mathbf{m M ~ h} \mathbf{h}^{-1}\right)\end{array}$ & $\begin{array}{l}(R) \text {-1-phenyl } \\
\text { ethanol }^{[b]} \\
(\mathrm{mM})\end{array}$ & $\mathrm{TTN}_{\mathrm{r} A a e \mathrm{UPO} \mathrm{O}^{[\mathrm{b}]}}$ & $\begin{array}{l}e e^{[b]} \\
(\%)\end{array}$ \\
\hline \multirow{5}{*}{$\mathrm{r}$ Aae $\mathrm{UPO}^{[\mathrm{c}]}$} & $25 \mathrm{nM}$ & $0.12 \pm 0.01$ & 0.087 & 3440.4 & $>99$ \\
\hline & $50 \mathrm{nM}$ & $0.25 \pm 0.02$ & 0.104 & 1760.2 & $>99$ \\
\hline & $100 \mathrm{nM}$ & $0.33 \pm 0.09$ & 0.182 & 1821.4 & $>99$ \\
\hline & $200 \mathrm{nM}$ & $0.62 \pm 0.15$ & 0.285 & 1362.8 & $>99$ \\
\hline & $300 \mathrm{nM}$ & $0.91 \pm 0.27$ & 0.485 & 1590.5 & $>99$ \\
\hline \multirow{5}{*}{$\mathrm{BiOCl}^{[\mathrm{d}]}$} & $0.2 \mathrm{mg} \mathrm{ml}^{-1}$ & $0.65 \pm 0.21$ & 0.275 & 884.3 & $>99$ \\
\hline & $0.4 \mathrm{mg} \mathrm{ml}^{-1}$ & $0.64 \pm 0.12$ & 0.298 & 996.4 & $>99$ \\
\hline & $0.6 \mathrm{mg} \mathrm{ml}^{-1}$ & $0.67 \pm 0.19$ & 0.308 & 1023.3 & $>99$ \\
\hline & $0.8 \mathrm{mg} \mathrm{ml}^{-1}$ & $0.83 \pm 0.32$ & 0.242 & 780.7 & $>99$ \\
\hline & $1.0 \mathrm{mg} \mathrm{ml}^{-1}$ & $0.85 \pm 0.23$ & 0.237 & 763.5 & $>99$ \\
\hline \multicolumn{6}{|c|}{$\begin{array}{l}\text { Determined after }{ }^{[\mathrm{a}]} 15-\mathrm{min} \text { and }{ }^{[\mathrm{b}]}\left[2 \mathrm{~h} \text { reaction, respectively. Reaction conditions: }{ }^{[\mathrm{cc}]}[\mathrm{BiOCl}]=1 \mathrm{mg}\right. \\
\mathrm{ml}^{-1} \text {; [ethylbenzene] }=100 \mathrm{mM} ;{ }^{\mathrm{d}]}[\mathrm{r} \text { Aae } U P O]=300 \mathrm{nM} \text {, [ethylbenzene] }=100 \mathrm{mM} .50 \mathrm{mM} \text { Tris } \\
\text { buffer (pH 7.0) is used as a buffer solution. All initial reaction rate values represent means } \pm \mathrm{SD} \text { (n } \\
=3 \text { ). }\end{array}$} \\
\hline
\end{tabular}




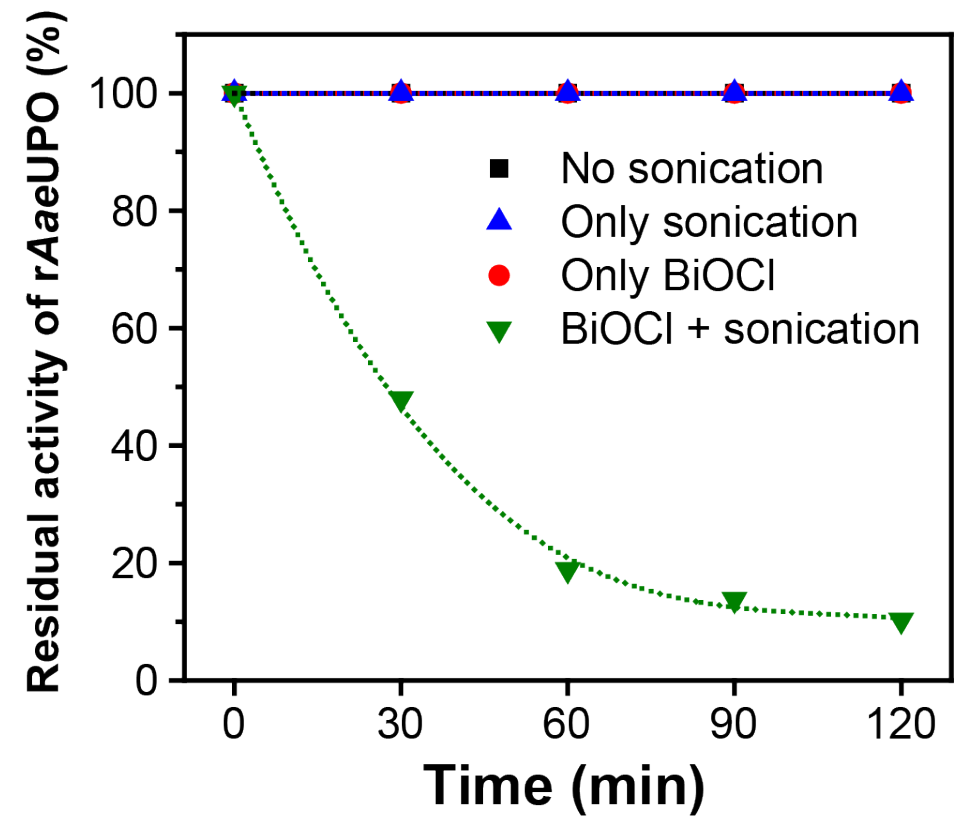

Figure S7. Effect of piezoactivated $\mathrm{BiOCl}$ on the residual activity of $\mathrm{r} A a e \mathrm{UPO}$. The residual activity of rAaeUPO was investigated using ABTS in different conditions. Reaction conditions: $1 \mathrm{mg} \mathrm{ml}^{-1} \mathrm{BiOCl} ; 200 \mathrm{nM} \mathrm{r}$ AaeUPO; $\mathrm{T}=25^{\circ} \mathrm{C}$; applied ultrasound $(40 \mathrm{kHz}, 70$ W); solvent: an $\mathrm{O}_{2}$-purged Tris buffer (50 mM, pH 7.0).

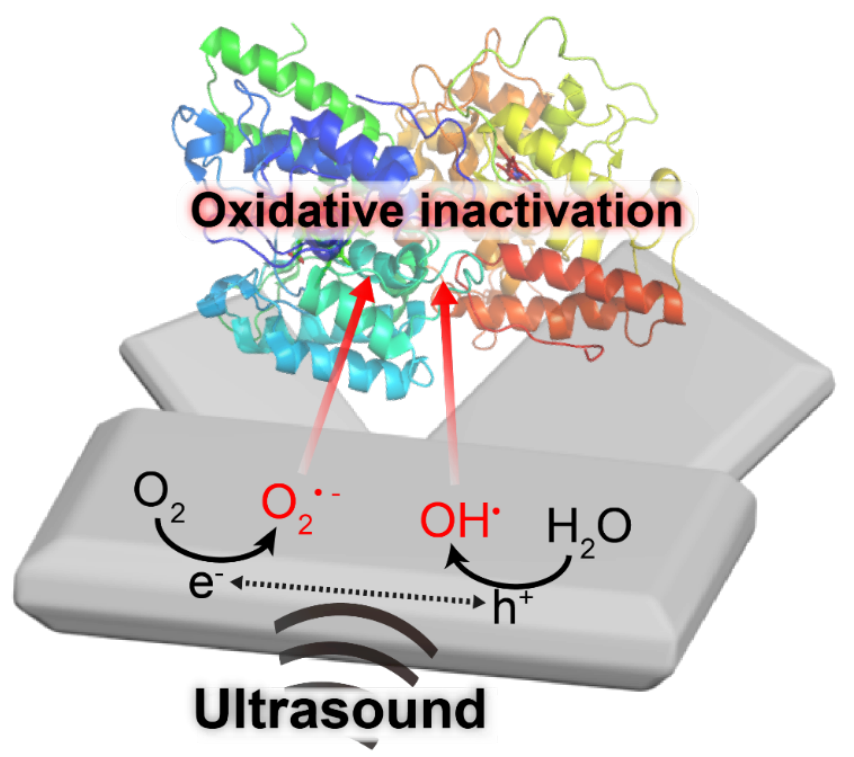

Figure S8. Oxidative inactivation of $\mathrm{r}$ AaeUPO. Schematic illustration of an oxidative inactivation of $\mathrm{r}$ AaeUPO by reactive oxygen species (ROS) including $\mathrm{O}_{2}{ }^{--}$and $\mathrm{OH}^{*}$. The piezoresonse of $\mathrm{BiOCl}$ generates electrons and holes, which react with $\mathrm{O}_{2}$ and $\mathrm{H}_{2} \mathrm{O}$, respectively, to form $\mathrm{O}_{2}{ }^{-}$and $\mathrm{OH}^{*}$. These ROS induce oxidative stress to enzymes, resulting in the irreversible inactivation of enzymes. 
a

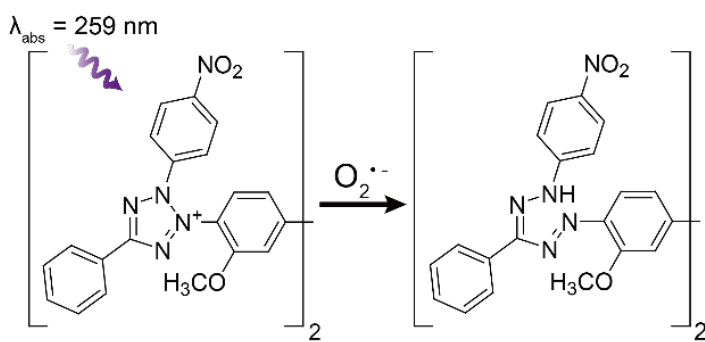

Nitro blue tetrazolium

(NBT)

C

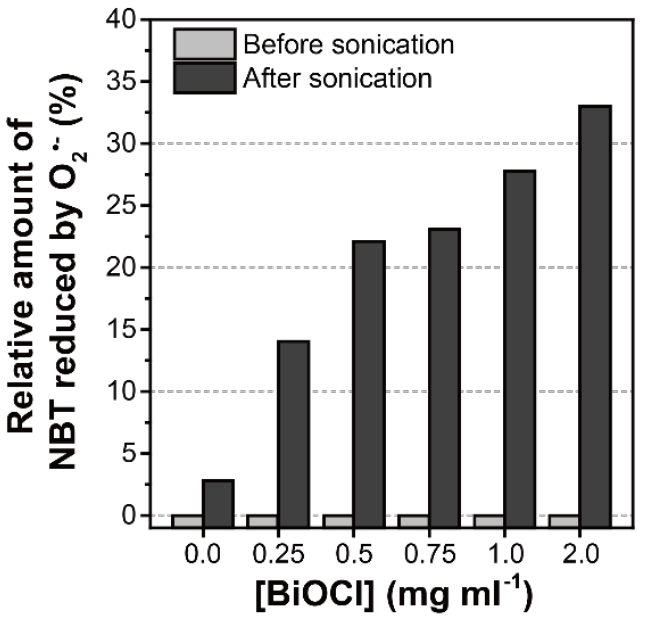

b

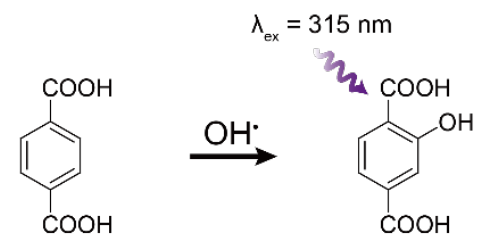

Terephthalic acid

(TA)

2-hydroxyterephthalic acid (HTA)

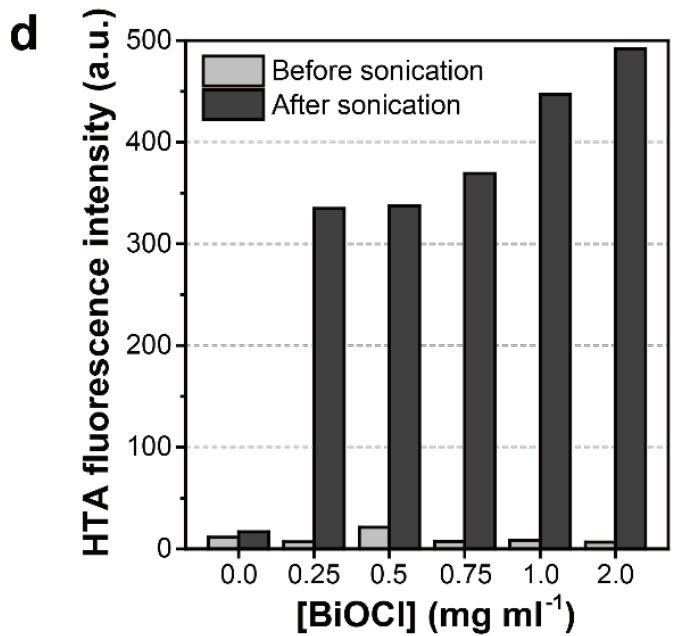

Figure S9. Use of NBT and TA assays for investigating the generation of superoxide and hydroxyl radicals. (A, B) Schematic of nitro blue tetrazolium (NBT) and terephthalic acid (TA) assays. (C) Relative amounts of superoxide radicals $\left(\mathrm{O}_{2}{ }^{-}\right)$with varying $\mathrm{BiOCl}$ concentration for 30-min ultrasonic irradiation $(40 \mathrm{kHz}, 70 \mathrm{~W})$. The absorption intensity was normalized to that of NBT solution incubated with BiOCl. (D) Effect of BiOCl concentration on the fluorescence intensity of HTA solution for 1-h ultrasonic irradiation $(40 \mathrm{kHz}, 70 \mathrm{~W})$. Solvent: an $\mathrm{O}_{2}$-purged Tris buffer (50 mM, pH 7.0). 
a

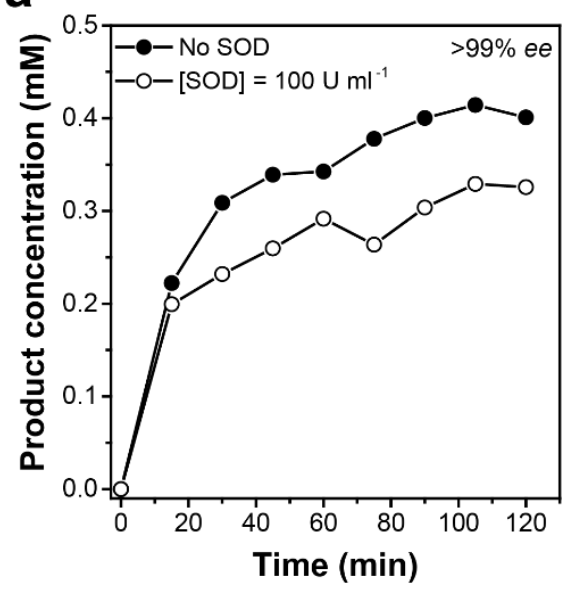

b

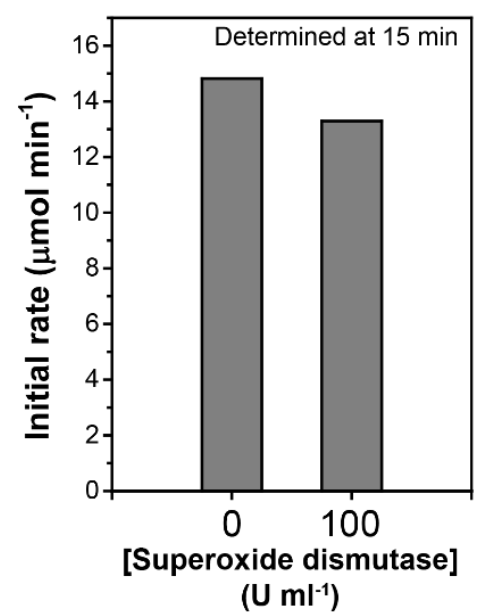

C

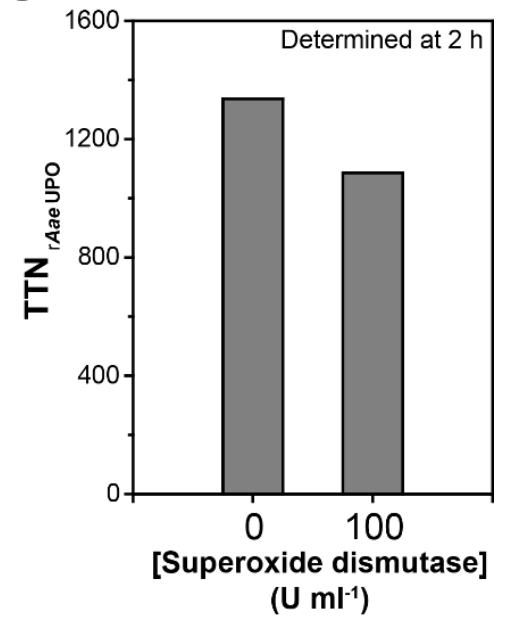

Figure S10. Influence of superoxide dismutases on piezobiocatalytic conversion of ethylbenzene. (A) Piezobiocatalytic production of total products $[(R)-1$-phenylethanol and acetophenone] in the absence and presence of $100 \mathrm{U} \mathrm{ml}^{-1}$ superoxide dismutases (SODs). (B) Initial reaction rate and $(\mathbf{C})$ total turnover number of AaeUPO $\left(\mathrm{TTN}_{\mathrm{r} A a e \mathrm{UPO}}\right)$ were calculated from the time profiles. Reaction conditions: $1 \mathrm{mg} \mathrm{ml}^{-1} \mathrm{BiOCl} ; 300 \mathrm{nM} \mathrm{r}$ AaeUPO; $100 \mathrm{mM}$ ethylbenzene; applied ultrasound $(40 \mathrm{kHz}, 70 \mathrm{~W})$; solvent: an $\mathrm{O}_{2}$-purged Tris buffer $(50 \mathrm{mM}$, $\mathrm{pH}$ 7.0). Initial reaction rate and $\mathrm{TTN}_{\mathrm{r} A a e \mathrm{UPO}}$ were determined by $\mathrm{GC}$ analyses at $15 \mathrm{~min}$ and 2-h reaction, respectively.

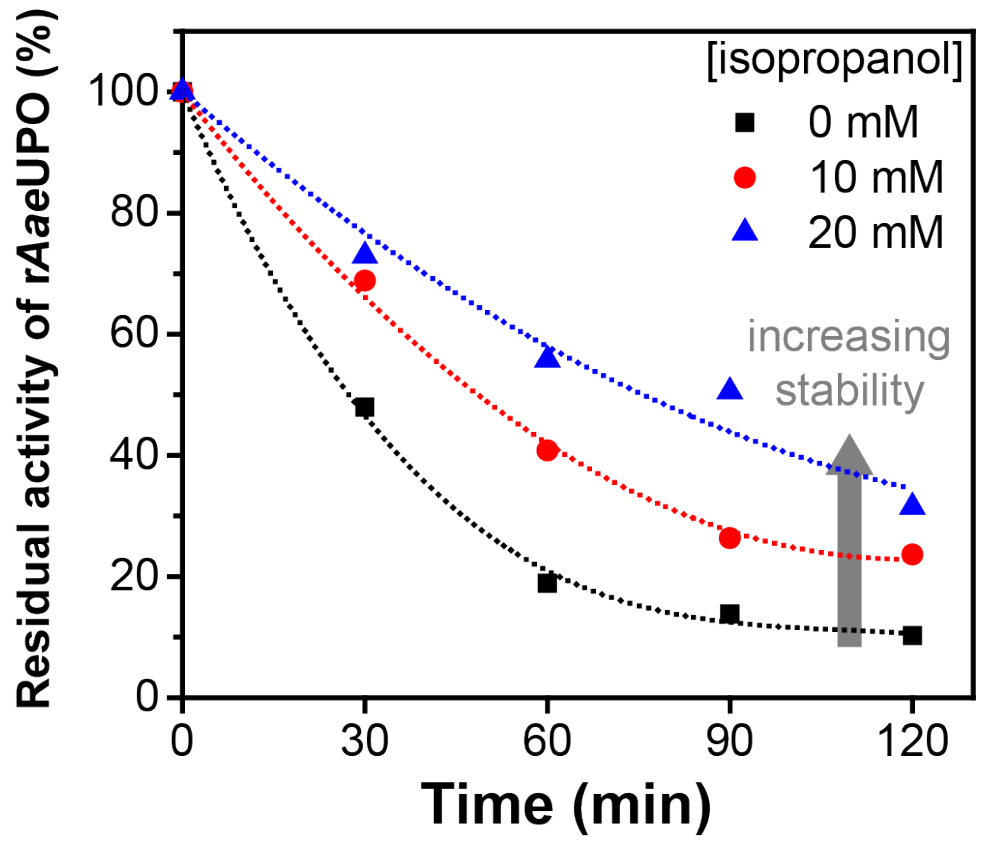

Figure S11. Effect of isopropanol on the residual activity of $\mathrm{rAaeUPO}$. Time profiles of the residual enzyme activity with varying isopropanol concentration from 0 to $20 \mathrm{mM}$. Reaction conditions: $1 \mathrm{mg} \mathrm{ml}^{-1} \mathrm{BiOCl} ; 300 \mathrm{nM} \mathrm{r}$ AaeUPO; $100 \mathrm{mM}$ ethylbenzene; applied ultrasound $(40 \mathrm{kHz}, 70 \mathrm{~W}) ; \mathrm{T}=25{ }^{\circ} \mathrm{C}$; solvent: an $\mathrm{O}_{2}$-purged Tris buffer $(50 \mathrm{mM}, \mathrm{pH} 7.0)$. 


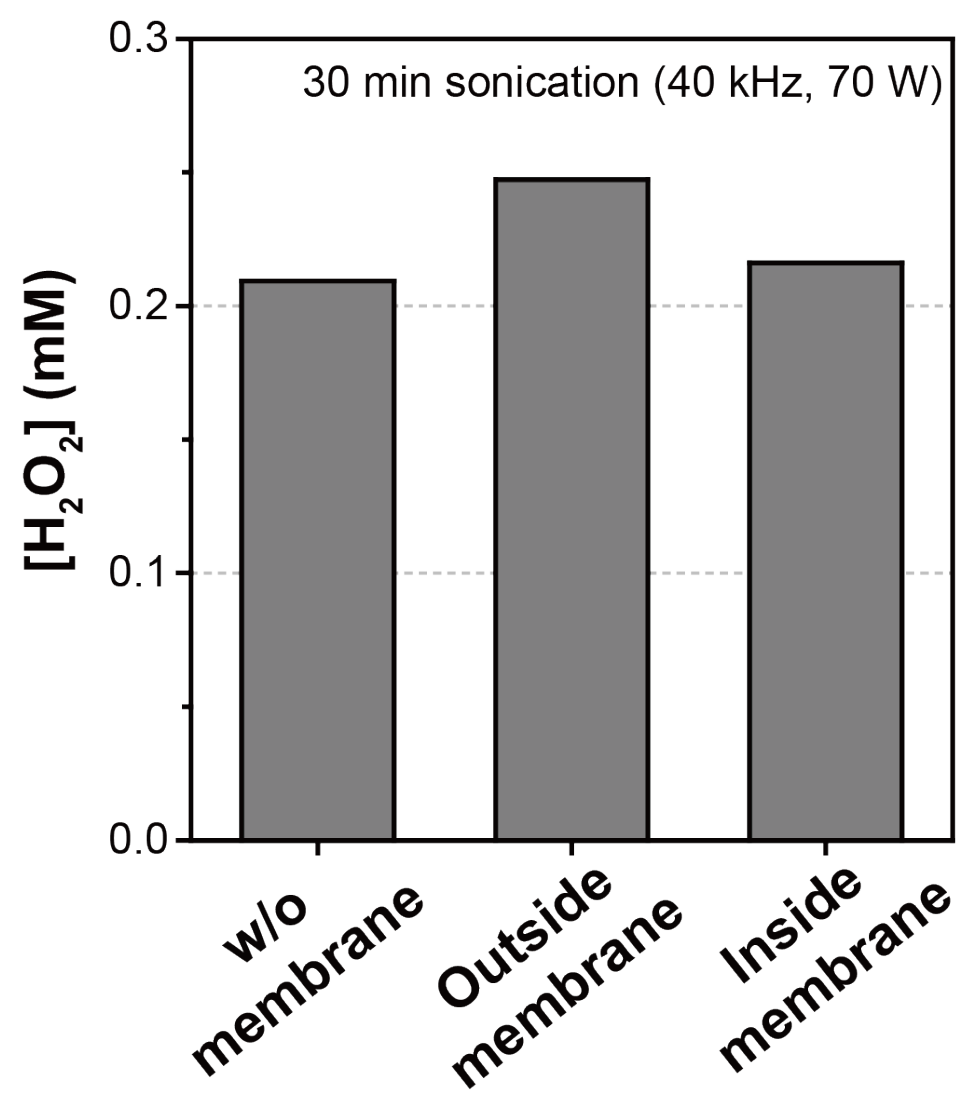

Figure S12. Effect of dialysis membrane on the production and the transport of $\mathrm{H}_{2} \mathrm{O}_{2}$. Reaction conditions: $1 \mathrm{mg} \mathrm{ml}^{-1} \mathrm{BiOCl}$; applied ultrasound $(40 \mathrm{kHz}, 70 \mathrm{~W})$; $\mathrm{T}=25^{\circ} \mathrm{C}$; solvent: an $\mathrm{O}_{2}$-purged Tris buffer $(50 \mathrm{mM}$, pH 7.0). Note that we used a dialysis membrane cellulose (molecular mass cutoff $=14 \mathrm{kDa}$ ). 


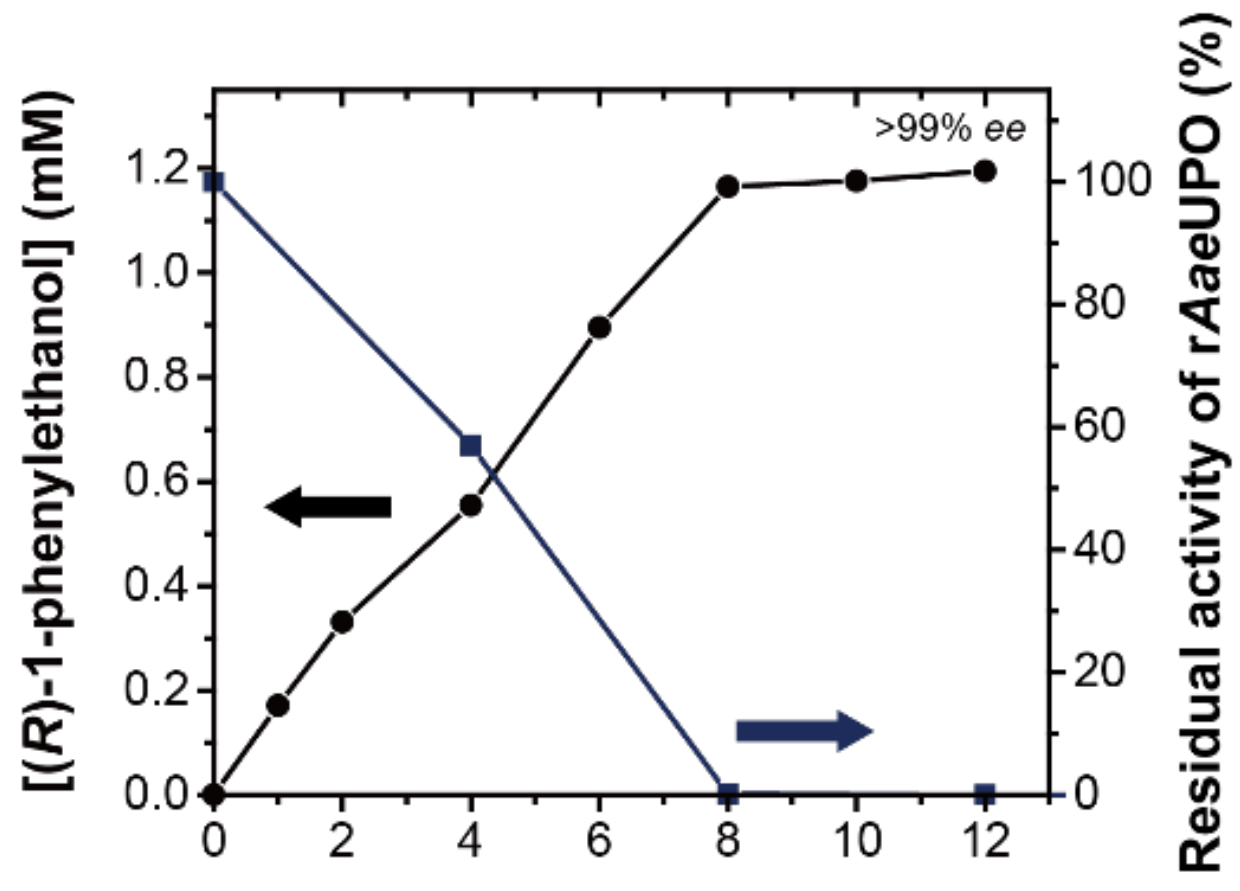

Time (h)

Figure S13. Piezobiocatalytic hydroxylation of ethylbenzne to $(R)-1$-phenylethanol using a spatially separated BiOCl-rAaeUPO system and the time profile of the residual enzyme activity. Reaction conditions: $1 \mathrm{mg} \mathrm{ml}^{-1} \mathrm{BiOCl} ; 300 \mathrm{nM} \mathrm{r}$ AaeUPO; $100 \mathrm{mM}$ ethylbenzene; applied ultrasound $(40 \mathrm{kHz}, 70 \mathrm{~W}) ; \mathrm{T}=25^{\circ} \mathrm{C}$; solvent: an $\mathrm{O}_{2}$-purged Tris buffer $(50 \mathrm{mM}$, pH 7.0). Note that we used a dialysis membrane cellulose (molecular mass cutoff $=14 \mathrm{kDa}$ ) to separate $\mathrm{BiOCl}$ from $\mathrm{r}$ AaeUPO. 


\section{References}

(1) Molina-Espeja, P.; Ma, S.; Mate, D. M.; Ludwig, R.; Alcalde, M. Tandem-yeast Expression System for Engineering and Producing Unspecific Peroxygenase. Enzyme Microb. Technol. 2015, 73-74, 29-33.

(2) Kim, K.; Lee, S. H.; Choi, D. S.; Park, C. B. Photoactive Bismuth Vanadate Structure for Light-Triggered Dissociation of Alzheimer's $\beta$-Amyloid Aggregates. Adv. Funct. Mater. 2018, 28, 1802813. 